\title{
A justificação dos direitos fundamentais não enumerados pelas cortes: uma tipologia
}

\author{
The justification of unenumerated fundamental rights by the \\ courts: a typology
}

\author{
Jane Reis Gonçalves Pereira ${ }^{1}$ \\ Gabriel Accioly Gonçalves ${ }^{2}$
}

\begin{abstract}
RESUMO
O estudo analisa as modalidades de justificação dos direitos fundamentais não enumerados usadas pelos tribunais, propondo uma tipologia dos fundamentos que lastreiam a sua construção pela via judicial. O objetivo é categorizar e avaliar os tipos de justificação que pavimentam teoricamente as teses que os tribunais empregam para atribuir validade jurídica aos direitos não listados nos textos constitucionais. Apontamos três linhas básicas de discursos que buscam justificar o reconhecimento de direitos não textuais: $i$ ) a dos direitos implicitamente previstos pela Constituição; ii) a de que tais direitos seriam alcançáveis pelo recurso aos valores e ideias de justiça socialmente dominantes num dado momento histórico; e iii) a dos direitos formulados pela via do costume constitucional. A partir da análise da motivação de decisões judiciais em matéria constitucional, constatou-se que os modelos aqui apresentados operam como tipos ideais, na prática podendo ser utilizados de forma combinada, sendo passíveis, ainda, de embasar construções argumentativas antagônicas ao reconhecimento de novos direitos.
\end{abstract}

\section{PALAVRAS-CHAVE:}

Direitos fundamentais, Direitos não enumerados, Interpretação constitucional.

\begin{abstract}
The study examines the types of justification used by the courts to build unenumerated fundamental rights, proposing a categorization of the arguments adopted by judges to identify them. The objective is to classify and analyze the modes of justification that provide theoretical basis to recognize the legal validity to rights not listed in constitutional texts. We point out three fundamental lines of discourse that seek to justify the recognition of non-textual rights: i) one that sees these rights as implicitly contained in the Constitution; ii) one that understands such rights as achievable using socially dominant values and ideas of justice at a given historical moment; and iii) one that claims that these rights are formulated through constitutional custom.

\footnotetext{
${ }^{1}$ Professora Associada de Direito Constitucional da Universidade do Estado do Rio de Janeiro (UERJ). Doutora em Direito Público pela UERJ. Mestre em Direito Constitucional e Teoria do Estado pela Pontifícia Universidade Católica do Rio de Janeiro (PUC-Rio). Juíza Federal. (janergp@gmail.com)

${ }^{2}$ Mestre em Direito Público pela Universidade do Estado do Rio de Janeiro. Analista Judiciário na Justiça Federal do Rio de Janeiro. (accioly.gabriel.uerj@gmail.com).
} 
When evaluating the reasoning of judicial decisions in constitutional matters, we affirm that the models presented function as ideal types, since in practice they are usually applied in a combined way. It was also observed that these models can also be used to support argumentative constructions contrary to the recognition of new rights.

\section{KEYWORDS:}

Fundamental rights, Unenumerated rights, Constitutional interpretation.

\section{INTRODUÇÃO}

Catálogos extensos e analíticos de direitos fundamentais são um traço distintivo do constitucionalismo contemporâneo. Algumas constituições, indo além das enumerações, enunciam cláusulas que afirmam textualmente a não exaustividade dos direitos por elas listados. É esse o caso da constituição brasileira (art. $5^{\circ}, \S 2^{\circ}$ ), bem como de outras, como a norteamericana (Nona Emenda), a portuguesa (art. 16, $1^{\circ}$ ), a colombiana (art. 94), a peruana (art. $3^{\circ}$ ). Essas disposições normatizam a ideia geral de que há direitos fundamentais fora do catálogo ou não enumerados, isto é, não formalmente especificados.

Entretanto, as cláusulas constitucionais que embasam os direitos não enumerados contêm pouca ou nenhuma orientação ao intérprete acerca de quais seriam tais direitos, ou sobre que critérios devem ser empregados para identificá-los. A possibilidade de criação e aplicação judicial de direitos extratextuais também não costuma ser mencionada explicitamente. Em verdade, tais cláusulas de abertura de direitos fundamentais ${ }^{3}$ explicitam um problema ancestral na interpretação jurídica, relativo às complexas relações entre direito escrito e não escrito, entre os dispositivos e a construção de significados normativos. Tanto é assim que, mesmo nos países cujas constituições não enunciam fórmulas de não exaustividade dos direitos, outros fundamentos normativos costumam ser empregados para reconhecer direitos fundamentais não enumerados. É o caso, por exemplo, do art. $2^{\circ}$, I, da Constituição alemã, bem como do art. $10^{\circ}$,

\footnotetext{
${ }^{3}$ A terminologia é de Jorge Miranda (2000, p. 162), que emprega, ainda, a expressão cláusula de atipicidade dos direitos fundamentais.
} 
I, da Constituição espanhola e do art. $2^{\circ}$ da Carta italiana, que consagram o direito ao livre desenvolvimento da personalidade, que, nos respectivos sistemas, costumam funcionar como referenciais para a criação de novos direitos pelos juízes.

Em sua origem, a noção de direitos não enumerados advém das concepções jusnaturalistas, que inspiraram a previsão dos direitos individuais nas primeiras constituições liberais (BARNETT, 1991, p. 629). Com a superação do jusnaturalismo clássico e a emergência das correntes positivistas e pós-positivistas, as teses que defendem que há direitos fundamentais que ultrapassam a base textual já não são apenas baseadas na defesa de uma razão abstrata e universal, assumindo novas configurações e formatos. Nesse contexto, é importante analisar as modalidades de justificação atualmente empregadas para reconhecer direitos fora do catálogo.

O presente trabalho procura suprir uma lacuna na análise teórica do tema no Brasil, propondo uma classificação das modalidades de motivação que lastreiam a construção de direitos não enumerados pela via judicial. Buscamos, nesse contexto, categorizar e analisar os modelos de justificação que pavimentam teoricamente as teses que lhes atribuem validade jurídica. Ao mesmo tempo, os modelos aqui apresentados poderão funcionar como ponto de partida teórico de uma agenda de pesquisa mais ampla, que busque analisar hipóteses específicas de construção judicial de direitos fundamentais fora do catálogo em diversos sistemas jurídicos.

Antes de prosseguir, dois esclarecimentos preliminares se mostram pertinentes. $\mathrm{O}$ primeiro diz respeito ao recorte temático adotado. O estudo desenvolvido tem por objeto os direitos fundamentais não escritos, assim entendidos os que não possuam qualquer fundamento textual, seja no catálogo, seja de forma esparsa ${ }^{4}$. O segundo trata de uma delimitação conceitual. Embora haja autores que os diferenciem ${ }^{5}$, utilizaremos os termos fundamentação e justificação

\footnotetext{
${ }^{4}$ Canotilho (2003, p. 404) denomina direitos fundamentais dispersos aqueles que tenham assento textual na constituição, mas fora do catálogo da Parte I da Lei Fundamental portuguesa. A noção também é admitida no direito brasileiro, sendo o exemplo clássico nesse sentido a regra da anterioridade tributária $(\mathrm{CF} / 88$, art. 150, III, "b") considerada garantia individual do contribuinte e cláusula pétrea pelo Supremo Tribunal Federal. Neste sentido, v. BRASIL. Supremo Tribunal Federal (Tribunal Pleno). ADI no 939. Relator: Min. Sydney Sanches. 15 dez. 1993. DJe 18 mar. 1994.

${ }^{5}$ A respeito, confira-se a lição de Alexy (2011, p. 46): "Há algumas diferenças, mas também pontos importantes de semelhança entre os conceitos de justificação e fundamentação de uma convicção, asserção, proposição etc. Por outro lado, o conceito de justificação é mais amplo do que o da fundamentação. Assim, pode-se falar de justificar uma expressão tanto quando o falante admite que não é motivada, mas era necessária para evitar males e quando de fato é motivada. Por outro lado, o conceito de justificação pode ser também mais restrito. Justificação é o termo usado, em particular, quando razões devam ser expostas para esclarecer objeções ou dúvidas. No entanto, em muitos contextos os dois conceitos podem ser igualmente usados".
} 
de modo intercambiável, entendidos como modalidades discursivas de motivação da decisão que reconheça um direito não enumerado.

\section{DISCURSOS DE JUSTIFICAÇÃO DOS DIREITOS FUNDAMENTAIS}

A noção de que há direitos que devem ser considerados como fundamentais, ainda que não listados em textos constitucionais, remonta a uma tradição tão antiga quanto o projeto constitucionalista inaugurado pelas revoluções liberais. O conceito de direitos não enumerados tem origem remota na tradição norte-americana, na qual o processo de emancipação colonial e a elaboração da Constituição de 1787 colheu inspiração filosófica em teorias contratualistas. De forma simplificada, essas concepções, já em suas formulações dos séculos XVII e XVIII, partem da noção de que o Estado não é uma realidade natural, derivada do poder divino ou de tradições imemoriais, mas uma construção artificial, elaborada por meio do contrato social, pactuado por pessoas dotadas de direitos naturais e movidas pela intenção de proteger esses direitos, ameaçados no estado de natureza (SANCHÍS, 2003, pp. 35 e ss.) ${ }^{6}$. Os direitos naturais, segundo essa linha de pensamento, são tidos como anteriores e superiores ao Estado (PELAYO, 1993, p. 150).

No plano da filosofia política que inspirou o constitucionalismo, tem destaque a ideia de que um dos atributos dos direitos humanos seria a universalidade, compreendida tanto na perspectiva da titularidade (de direitos pertencentes a todos os seres humanos, independentemente das posições sociais que ocupem), quanto de conteúdo. Nessa linha, John Locke, cuja obra inspirou os primeiros movimentos constitucionalistas, definia a liberdade natural como o poder de ordenar ações e dispor sobre posses conforme a vontade do titular, em conformidade com os limites da lei da natureza e sem dependência da vontade de outrem

\footnotetext{
${ }^{6}$ Conforme ensina Sanchís (2003, p. 35 e ss.), a teoria do contrato social foi responsável por uma subjetivização do direito natural, gradualmente substituído pela noção de direitos individuais. É que, enquanto na tradição jusnaturalista de origem divina prevalecia o entendimento do direito como fruto de uma ordem objetiva universal, que assinalaria a cada indivíduo seus direitos e deveres, com as teorias contratualistas, opera-se uma inversão dessa lógica. Enquanto na era medieval a lei divina conferia embasamento às pretensões individuais, agora estas é que se convertem em fundamento das instituições, responsáveis por conformar a ordem jurídica objetiva.
} 
(LOCKE, 2003, p. 101). Em seu modelo teórico, os direitos civis decorrem da condição de membro da sociedade organizada por um contrato (Ibidem, p. 244).

Já no plano jurídico, prevalecia a ideia de que os direitos naturais, uma vez positivados, convertem-se em direitos constitucionais. De acordo com essa linha de pensamento, o fato de, eventualmente, alguns dos direitos naturais não serem enunciados em catálogos de direitos não significa que eles deixariam de ter esse caráter, em virtude de sua inerência à condição humana (MARCOS, 2000, p. 17). De fato, na perspectiva jusnaturalista então hegemônica, a validade dos direitos naturais não decorre da sua positivação em documentos formais, mas da razão humana, por meio da qual se alcança uma justiça objetiva antecedente ao direito positivo (SANCHÍS, 2003, p. 38).

O texto da Nona Emenda à Constituição norte-americana - historicamente, a primeira cláusula de abertura do catálogo de direitos fundamentais (MIRANDA, 2000, p. 163) -, ilustra bem a concepção, à época amplamente aceita, de que tais garantias consistiriam em direitos naturais: "A enumeração na Constituição de certos direitos não deve ser interpretada de modo a negar ou descreditar outros retidos pelo povo" 7 .

O fato de o texto da emenda ter empregado o vocábulo "retidos" demonstra a noção de que se trata de direitos que, na compreensão dos constituintes, seriam titularizados pelos seres humanos em caráter inerente e de forma anterior à elaboração da Constituição (ANDRADE, 1998, p. 77).

Já não é incontroversa, nos dias atuais, a noção de que os direitos não listados - bem como os direitos fundamentais em geral - possuiriam caráter inato e universal. De fato, a noção de universalidade dos direitos, passado o apogeu do jusnaturalismo, passa a sofrer uma série de críticas de diversas correntes teóricas. $\mathrm{Na}$ perspectiva histórica, argumenta-se que tal concepção, embora concebida de forma espacial e temporalmente situada, pretende ultrapassar as fronteiras do contexto em que fora criada. Já o aspecto jusnaturalista da concepção de

\footnotetext{
${ }^{7}$ Foi no contexto de hegemonia da teoria dos direitos naturais que o constitucionalismo norte-americano, ao positivar as emendas instituidoras do catálogo de direitos fundamentais - o Bill of Rights de 1791 -, incorporou a Nona emenda à Constituição. A proposição da emenda por James Madison decorreu do receio manifestado por Hamilton, em 1787, de que a sua inexistência viesse a ser interpretada como uma autorização implícita ao governo federal para violar os demais direitos naturais (ABRAMS, 1988, p. 94). Além do argumento textual, o histórico de debates parlamentares acerca da adoção do Bill of Rights confirma essa leitura. Os congressistas que defenderam as emendas consagradoras de direitos fundamentais ressaltavam a circunstância de que algumas delas desempenhariam a função de positivar, em caráter declaratório, direitos já existentes (AMAR, 2012, p. 102).
} 
universalidade (caráter inato e pré-estatal) passa pelo crivo da crítica positivista, que sustenta que os direitos somente se aperfeiçoam quando incorporados ao ordenamento positivo ${ }^{8}$.

Não apenas a fonte formal dos direitos não escritos passa a ser contestada. A universalidade passa a sofrer questionamentos críticos também do ponto de vista do conteúdo material dos direitos. Num primeiro plano, defensores do relativismo cultural e nacionalistas enxergam nos discursos de expansão dos direitos humanos a todos os povos um perigoso mecanismo de imposição de valores eurocêntricos em um mundo multicultural (MARTINEZ, 1994, p. 620) ${ }^{9}$. Outra fonte de questionamentos é proveniente do ceticismo ético, que, de forma resumida, parte da noção de que não existiria, objetivamente, um único conteúdo correto da moral a ser atingido pela razão humana, não sendo possível classificar proposições morais como verdadeiras ou falsas, por seu caráter subjetivo e relativo (NINO, 2010, p. 35-36).

Paralelamente, a ideia de que certos direitos surgem das lacunas do ordenamento jurídico tornou-se corrente no pensamento jurídico contemporâneo (LARENZ, 1997, p. 519). Neste sentido, o abandono da pretensão de que o ordenamento jurídico contenha normas expressas para todas as situações que reclamam a regulação jurídica também se manifesta no campo dos direitos humanos, sobretudo com o fortalecimento da percepção de que os esforços de catalogação de direitos são insuficientes para conter todas as ameaças às liberdades e garantias básicas, que se renovam com o avanço das sociedades (ALEXY, 2008, p. 369). Também a ampla consagração internacional do valor da dignidade humana no pós-Guerra, associada à evolução do entendimento acerca das exigências de uma vida digna, irrigam o sistema de direitos fundamentais como valores multidimensionais, propiciando o reconhecimento de novos direitos.

Por outro lado, se o papel dos tribunais de colmatar lacunas na aplicação do direito, por si só, é visto como causa de riscos democráticos, essa preocupação se intensifica na seara da jurisdição constitucional, já que a proteção a direitos constitucionais não escritos é frequentemente associada à invalidação de leis que os contrariem. Há o natural receio de que

\footnotetext{
${ }^{8}$ Para um aprofundamento da discussão sobre a ideia de universalidade dos direitos humanos, v. MARTINEZ, 1994, pp. 617 e ss. e LAPORTA, 1987.

${ }^{9}$ Sobre o multiculturalismo, v. KYMLICKA, 1989.
} 
os juízes passem a impor suas preferências pessoais ao julgar questões constitucionais com base em normas sem lastro textual imediato ${ }^{10}$.

Essas linhas de contestação não significaram, entretanto, que a jurisprudência constitucional dos variados países tenha deixado de construir novos direitos fundamentais sem fundamento textual expresso nas constituições. Todas essas reformulações críticas indicam que os modelos de fundamentação dos direitos fundamentais não enumerados passaram por atualizações. Nessa ordem de ideias, é possível identificar, em um período mais recente, três linhas básicas de discursos que buscam justificar o reconhecimento de direitos não textuais: $i$ ) a dos direitos implicitamente previstos pela Constituição; ii) a de que tais direitos seriam alcançáveis pelo recurso aos valores e ideias de justiça socialmente dominantes num dado momento histórico; e iii) a dos direitos formulados pela via do costume constitucional. É importante destacar que as categorias de motivação em questão operam por tipos ideais. É que esses modelos de fundamentação nem sempre são utilizados de forma isolada, e, em geral, se influenciam reciprocamente. Não raro, a construção de um novo direito envolve o uso conjugado de mais de uma modalidade de motivação. Além disso, os discursos mencionados podem ser evocados também como fundamento para negar proteção a um potencial novo direito. Em casos altamente controvertidos, as justificações passam por elaborações conflitantes, podendo funcionar como arena de disputa por resultados argumentativos opostos. Apesar dessas complexidades, cada uma das fórmulas de fundamentação envolve uma estrutura argumentativa particular, que justifica um tratamento apartado, como demonstramos a seguir.

\subsection{Direitos implícitos}

É possível agrupar as linhas de pensamento a respeito dos direitos fundamentais implícitos em três vertentes básicas: $a$ ) a que nega a existência de proteção constitucional a tais formulações, considerando não normativas as cláusulas constitucionais que preveem a abertura dos catálogos de direitos; $b$ ) a que admite a existência de direitos implícitos, porém rejeita a noção de que haveria uma diferença estrutural entre os direitos enumerados e não enumerados;

\footnotetext{
${ }^{10}$ John Hart Ely (2010, p. 45) é um exemplo de autor que manifesta essa crítica.
} 
e, por fim, $c$ ) a que admite a existência de direitos fundamentais enumerados (explícitos) e não enumerados (implícitos) como categorias apartadas.

A vertente de recusa à categoria dos direitos implícitos tem maior proeminência nos Estados Unidos, mais especificamente, nas controvérsias a respeito da interpretação da Nona Emenda à Constituição desse país.

A Nona Emenda não tem, tradicionalmente, grande peso nos debates acadêmicos ${ }^{11}$, nem é habitualmente invocada como fundamento em decisões judiciais. É conhecida a menção à ocasião em que o Juiz Bork, ao ser sabatinado para ocupar o cargo de membro da Suprema Corte, afirmou que haveria um borrão de tinta sobre o texto dessa emenda, a qual seria ininteligível e desimportante ${ }^{12}$. Também costuma ser lembrada a afirmativa de Richard Posner (1992, p. 441) de que a Nona Emenda conferiria um cheque em branco às Cortes ${ }^{13}$.

A concepção não normativa da Nona Emenda colide fortemente com as linhas mais progressistas da Suprema Corte norte-americana, que chegou a invocá-la ao fundamentar o reconhecimento do direito implícito à privacidade marital, o qual, na terminologia do tribunal, estaria situado na zona de penumbra da constituição. Nas palavras do juiz Goldberg:

\begin{abstract}
"Atingindo a conclusão de que o direito à privacidade marital é protegido, ao estar dentro da protegida penumbra de garantias específicas do Catálogo de Direitos, a Corte refere-se à Nona Emenda, eu acrescento essas palavras para enfatizar a relevância dessa Emenda para a decisão da Corte. (...) Estabelecer que um direito tão básico e fundamental e tão profundamente enraizado em nossa sociedade como o direito à privacidade marital pode ser violado porque esse direito não está garantido pelas várias palavras das oito primeiras emendas à Constituição é ignorar a Nona Emenda e não lhe conferir quaisquer efeitos."14 (tradução livre)
\end{abstract}

As linhas argumentativas que buscam negar normatividade a essa emenda costumam partir de leituras a respeito das intenções dos constituintes ao positivá-la, aspecto que, por se

\footnotetext{
${ }^{11}$ De acordo com John Hart Ely (2010, p. 45), "[n]os círculos jurídicos mais sofisticados, a menção da Nona Emenda é um método infalível de provocar risos. ('O que você vai usar para fundamentar seu argumento, Lester? A Nona Emenda?')".

${ }^{12}$ Bork teve sua indicação rejeitada pelo Senado em outubro de 1987 e, na avaliação de Randy Barnett, a sua opinião sobre a Nona Emenda teve peso no desfecho desfavorável de sua sabatina, devido ao descompasso com a visão de grande parte da população americana, que enxerga os direitos contidos no Bill of Rights como inatos, desempenhando o Estado, apenas, o papel de protegê-los. Cf. BARNETT, 2005, p. 79.

${ }^{13}$ Em sentido oposto, v. ABRAMS, 1967, p. 1033-1039.

${ }^{14}$ ESTADOS UNIDOS DA AMÉRICA. Suprema Corte. Griswold vs. Connecticut, 381 U.S. 479 (1965). Sinteticamente, através dessa decisão, a Suprema Corte norte-americana reconheceu o direito ao uso de contraceptivos por pessoas casadas, com fundamento no direito à privacidade.
} 
tratar de tema de pouco interesse fora do debate norte-americano, não será enfatizado nesse estudo $^{15}$.

Assim, serão destacadas aqui apenas as abordagens normativas da cláusula em questão, assim entendidas as que partem da premissa de que a previsão constitucional de direitos fundamentais não enumerados encerra implicações jurídicas.

No que diz respeito à vertente de rejeição da diferença estrutural entre os direitos enumerados e não enumerados, nenhum autor possui mais destaque do que Ronald Dworkin ${ }^{16}$. Segundo esse filósofo, essa pretensa distinção não passa de um artifício argumentativo, caracterizando, em verdade, uma forma de se engendrar, subliminarmente, uma aura de suspeição acerca da validade dos direitos enquadrados como não enumerados, na medida em que supostamente carecedores de um fundamento textual e, portanto, mais frágeis do ponto de vista jurídico. Para o autor, tanto os direitos usualmente tidos como enumerados e aqueles, não enumerados, são fundamentados a partir de expedientes interpretativos que não diferem significativamente ${ }^{17}$. Conforme sustenta, tal oposição caracteriza uma concepção interpretativa excessivamente limitada e formalista, escrava de uma literalidade estrita e incompatível com as correntes teóricas de interpretação dos direitos fundamentais que admitem seu caráter normativo. Dworkin exemplifica o argumento mencionando como, de um lado, tanto os direitos à não discriminação com base no gênero e à queima da bandeira, quanto, de outro, o direito ao aborto são extraídos de cláusulas constitucionais abstratas. A despeito de todos esses direitos serem construídos por meio de interpretação - pois nenhum deles é mera expressão literal dos enunciados normativos que os embasam -, somente o terceiro direito é tido como não enumerado, buscando-se, a partir desse enquadramento, desqualificar seu caráter de genuíno

\footnotetext{
15 De forma sintética, essas teses argumentam que a disposição tem por objetivo esclarecer que os argumentos políticos não se limitam aos direitos constitucionalmente explicitados; que busca proteger o direito estadual contra interferências federais; que visa a esclarecer que outros direitos poderiam ser criados pelo legislador federal, porém a nível infraconstitucional; e que, embora possam existir direitos não enumerados, eles não são judicialmente aplicáveis. Para uma explicação detalhada dessas teses, argumentando-se por que nenhuma delas é consistente, devendo a interpretação mais intuitiva da nona emenda prevalecer, v., para as duas primeiras: SAGER, 1988, pp. 241 e ss. Sobre a terceira tese, v. ELY, 2010, p. 49. Esses argumentos, à exceção do último, negam a noção de direitos fundamentais não enumerados por meio de análises históricas alternativas à anteriormente apresentada sobre a intenção do constituinte ao positivar a Nona Emenda.

${ }^{16}$ A mesma orientação é adotada por Cristina Queiroz (2002, p. 94).

17 Como se sabe, uma das teorias formuladas por Dworkin que se celebrizou é a de que certos dispositivos constitucionais, por possuírem uma linguagem marcadamente abstrata, devem ser compreendidos como positivadoras de princípios morais sobre decência política e justiça, reclamando, assim, uma leitura moral. Cf. DWORKIN, 1996
} 
direito constitucional (DWORKIN, 1992, p. 387-388) ${ }^{18}$. Dessa forma, arremata o autor, como nenhum dos três direitos decorre exclusivamente da leitura textual dos dispositivos empregados na fundamentação do seu reconhecimento, sem distinções relevantes no processo interpretativo pelo qual são construídos, não se sustenta a pretensa distinção conceitual entre direitos listados ou não pela constituição (Ibidem, loc. cit.). Em ambos os casos, o que haveria seria uma categoria única, a de direitos implícitos. A Constituição não escrita, pois, é muito mais estabelecida do que a denominação de certos direitos como não enumerados, em oposição a outros, sugere. Outro exemplo que poderia ser mencionado é a jurisprudência que ampara a liberdade de associação com base na Primeira Emenda, cujo texto não menciona explicitamente, sem que se costume questionar o seu caráter enumerado.

A formulação de Dworkin tem como aspecto positivo destacar que a prática de proteção judicial de direitos não contidos na literalidade dos enunciados normativos é generalizada na história da suprema corte norte-americana. Neste sentido, opor-se ao reconhecimento judicial de direitos implícitos equivale a contestar a jurisdição constitucional nos moldes em que é praticada no contexto contemporâneo. Vale observar, entretanto, que a posição de Dworkin está inserida na sua concepção mais ampla a respeito do direito produzido pelos tribunais, segundo a qual este não envolveria dimensões criativas, cabendo ao juiz, nas controvérsias constitucionais, tão somente desvelar conteúdos normativos já existentes no ordenamento, ainda que de forma implícita ${ }^{19}$.

Por fim, tem-se a concepção que reconhece os direitos implícitos, diferenciando-os daqueles tido como explícitos. É essa a vertente majoritária, ainda que, dentro desse campo, haja uma multiplicidade de perspectivas. Como ponto de partida dessa concepção, é pertinente retornar ao debate a respeito da Nona Emenda norte-americana. A discussão lá travada dialoga

\footnotetext{
${ }^{18}$ No mesmo sentido, v. JR., 2004, p. 141.

${ }^{19}$ Segundo Dworkin, defesas da criatividade judicial - ou, na sua terminologia, da existência de discricionariedade judicial em sentido forte - refletem uma incompreensão de duas categorias distintas de raciocínio, correspondentes às questões de política e de princípio. Sinteticamente, enquanto as primeiras correspondem à justificação de uma decisão por promover um bem à coletividade, as segundas dizem respeito ao reconhecimento de direitos decorrentes de exigências da moralidade. Conforme esse autor, os juízes devem decidir apenas à luz das questões de princípio, sob pena de exercerem uma discricionariedade equivalente à do legislador, criando direito novo $e x$ post facto, no lugar de aplicar os direitos já contidos no ordenamento. A respeito, cf. DWORKIN, 1975, pp. 1058 e ss. Para uma discussão mais abrangente sobre as teorias que negam a dimensão criativa da atividade jurisdicional, v. GONÇALVES, 2016, pp. 15 e ss.
} 
com o sistema constitucional brasileiro, que colheu inspiração naquele modelo ao positivar a cláusula de não exaustividade dos direitos listados.

Dentre as vertentes que enxergam normatividade na Nona Emenda - caminho para o reconhecimento de direitos fundamentais implícitos no direito norte-americano -, o nível mais basilar de conteúdo que se atribui a esse enunciado é o de que ele consagraria uma norma interpretativa. Para essa vertente, a referida cláusula seria vazia de conteúdo, isto é, não conteria, em si mesma, os demais direitos a que faz referência, nem seria possível, exclusivamente pela sua leitura e interpretação, criá-los. Seguindo essa linha, Laurence Tribe e Michael Dorf afirmam ser um erro falar em "direitos da Nona Emenda". Para os autores, o dispositivo insculpe uma regra de interpretação prevista no texto constitucional, apenas indicando a máxima de que a ausência de fundamento textual explícito a um direito não significa, automaticamente, que ele inexista (TRIBE; DORF, 1991, p. 54) ${ }^{20}$. De forma similar, Akhil Reed Amar afirma que o dispositivo enuncia que todo o texto constitucional deve ser interpretado sob uma ótica favorável aos direitos, permitindo extrair novos conteúdos positivos da Constituição, e não de forma restritiva (AMAR, 2012, p. 101) ${ }^{21-22}$. Dito de outra forma, a Nona Emenda veda que o intérprete conceba a ausência de determinado direito no catálogo como um silêncio eloquente constitucional, que significaria, implicitamente, a sua exclusão ${ }^{23}$.

\footnotetext{
${ }^{20}$ No mesmo sentido, v. GREY, 1975; TUSHNET, 2007, p. 17; RAPACZYNSKI, 1998, p. 207. Esse último autor apresenta a especificidade de elastecer o argumento a um nível mais ousado. Embora filie-se à linha de que a emenda é vazia de conteúdo, Rapaczynski a considera irrelevante, já que sustenta que direitos implícitos continuariam a ser extraídos da Constituição mesmo se inexistente tal dispositivo. Por isso, defende que a única leitura proveitosa possível da mencionada disposição é a de que tal norma efetuaria um convite ao reconhecimento de direitos não enumerados através de fontes que, inexistindo a emenda, não poderiam ser consistentemente extraídas do texto constitucional por si só. Dentre as possíveis fontes cogitadas pelo autor, a que lhe parece suscitar menos receios seria a da proteção a direitos que promovam as finalidades subjacentes à Constituição, as quais devem ser identificadas pela leitura de seu texto.

${ }^{21}$ De forma associada a isso, o autor afirma que a Nona Emenda contempla, em seu núcleo, um direito não enumerado a se descobrir novos direitos. No mesmo sentido de que a cláusula impõe uma interpretação do restante da Constituição numa ótica favorável a busca de novos direitos, v. ARNOLD, 1988, p. 265-268.

${ }^{22}$ No plano filosófico, essa interpretação da Nona Emenda vai de encontro com concepções que criticam e buscam infirmar discursos de ampliação de direitos. Nessa ótica, de acordo com a crítica comunitarista, a desmesurada ampliação de direitos reconhecidos parte de concepções individualistas e egoístas, que desconsideram como da previsão de um novo direito decorrem responsabilidades a serem arcadas pela comunidade, de modo a tornar possível a sua implementação. Segundo Amitai Etzioni, um autor comunitarista, há uma tendência a que veiculadores de discursos de atribuição de novos direitos, não obstante, eximam-se de suas responsabilidades perante a coletividade. Por conta disso, entende que essa associação entre, de um lado, discursos simpáticos ao aumento do acervo de direitos e, de outro, fugas de responsabilidades, tende a provocar um ambiente social anárquico, que prejudica o atingimento de consensos e a formação de compromissos, em prejuízo da solidariedade social e dos laços que unem a comunidade. Etzioni chega a defender uma moratória no reconhecimento de novos direitos, bem como que os atualmente reconhecidos como tais passem por um reexame, de modo a serem "eliminados" aqueles que moralmente não mereçam tal status. V. ETZIONI, 1996, pp. 6 e ss.

${ }^{23}$ Sobre o silêncio eloquente constitucional, v. SARMENTO; NETO, 2013, p. 534.
} 
A observação vale também para o cenário brasileiro, com a diferença de que, o art. $5^{\circ}, \S 2^{\circ}$, da CF/88 não se limita a enunciar a existência de outros direitos, mas vai além disso, estabelecendo o critério hermenêutico de que esses direitos devem ser procurados na interpretação do regime e princípios previstos na Constituição, bem como em tratados internacionais dos quais o Brasil seja signatário.

Embora a diretriz hermenêutica de que a Nona Emenda exige que a Constituição seja interpretada favoravelmente ao reconhecimento de novos direitos possa parecer não contribuir para acessar o seu conteúdo, ela tem o mérito de uma vez adotada, tornar insustentável o argumento de que o silêncio constitucional corresponderia à negativa de proteção.

Randy Barnett, um dos autores que dedicou mais atenção ao tema, considera que a norma enunciada na Nona Emenda corresponde a uma máxima de interpretação do direito que firma presunção favorável às liberdades. Segundo o autor, os direitos de liberdade protegem um domínio no qual indivíduos e associações teriam autonomia para agir como lhes aprouver. Como não seria possível enumerar de antemão todas as condutas que poderiam ser realizadas nessa esfera de liberdade, torna-se necessário positivar uma cláusula aberta protetora dessas condutas (BARNETT, 1991, p. 626). Não consideramos essa concepção acertada. De um lado, o texto normativo em questão emprega o vocábulo "direitos" (rights) e não "liberdades" (freedoms), de modo que a restrição parece injustificada. De outro, a liberdade já possui assento em outras cláusulas constitucionais, de modo que interpretar a Nona Emenda (e, eventualmente, disposições análogas de outras constituições que também contemplem expressamente a liberdade) dessa forma implicaria recusar que tenha sentido normativo autônomo.

Ademais, essa interpretação restringe injustificadamente os tipos de direitos não enumerados dignos de proteção. Por essa perspectiva, direitos não enumerados calcados no valor da igualdade não poderiam ter sua proteção constitucional sediada nesse dispositivo. Não há fundamento idôneo para interpretar a norma em questão de modo a promover essa exclusão. Pelo contrário, normas dessa natureza possuem como característica constitutiva uma abertura ímpar $^{24}$, não sendo a liberdade sua única fonte valorativa. O entendimento em questão é defendido para todas as ordens constitucionais que contenham catálogos de direitos fundamentais fundados em outros valores, além do da liberdade e que prevejam cláusulas de

\footnotetext{
${ }^{24}$ É o que entende SARLET, 2001, p. 91.
} 
abertura do sistema de direitos fundamentais. No âmbito português, por exemplo, Jorge Miranda (2000, p. 165-166) defende o caráter não enumerado dos direitos econômicos, sociais e culturais.

Em verdade, o entendimento de Barnett se aproxima, ao menos em linhas gerais, do conceito de direito geral de liberdade. A questão coloca em pauta saber se os direitos textualmente enumerados "encontram diante de si um direito geral de liberdade ou o simples vazio jurídico" (SANCHÍS, 1990, p. 158). Segundo as leituras que reconhecem essa ideia, as liberdades enumeradas não são categorias autônomas que emergem da sua positivação, mas meras "especificações de um direito geral de liberdade" (Ibidem, p. 157). Essa noção pressupõe que "tudo que não está constitucionalmente proibido ou ordenado está permitido" (Ibidem, loc. cit.).

A base constitucional para invocar o direito geral à liberdade é diferente em variados sistemas. No direito alemão, Robert Alexy sustenta que esse direito tem sede no art. 2.1 da Lei Fundamental, que consagra o direito ao livre desenvolvimento da personalidade (ALEXY, 2008, pp. 341 e ss), entendimento adotado, também, pela Corte Constitucional alemã ${ }^{25}$. No constituticionalismo espanhol, Luis Prieto Sanchís (1990, pp. 161 e ss.) afirma que o direito geral de liberdade pode ser extraído do art. 16.1 da Constituição, que estabelece o direito à liberdade religiosa e ideológica. Na Constituição brasileira, é possível fundamentar o direito geral de liberdade no art. $5^{\circ}$, caput, que consagra o direito à liberdade, bem como no art. $5^{\circ}$, II, que determina que "ninguém será obrigado a fazer ou deixar de fazer alguma coisa senão em virtude de lei”, veiculando, a contrario sensu, uma cláusula geral de liberdade. Também o direito à liberdade de consciência, positivado no art. $5^{\circ}$, VI, pode fundamentar um direito à liberdade genérica (PEREIRA, 2018, p. 210-211).

Os dispositivos que embasam a ideia de direito geral de liberdade, de forma similar às cláusulas de não exaustividade, funcionam como ponto de partida para construção interpretativa

${ }^{25} \mathrm{O}$ direito geral de liberdade foi reconhecido pela Corte Constitucional alemã no conhecido caso Elfes. ALEMANHA. Tribunal Constitucional Federal da Alemanha. 6 BVerfGE 32, 197 (1957). O precedente tratou de impugnação à constitucionalidade de lei que restringia a concessão de passaportes, em caso de risco à segurança interna, ou externa, ou outros interesses vitais do Estado. Segundo a Corte, embora a Constituição Federal alemã não preveja, em caráter expresso, o direito a viajar para o exterior, essa liberdade não seria totalmente destituída de proteção constitucional, tendo em vista a existência de uma liberdade geral de ação, contida no art. 2.1, da constituição desse país. O pedido de inconstitucionalidade foi julgado improcedente, sob o entendimento de que, embora abusos na negativa de concessão de passaportes sejam possíveis, tal não fora o caso no litígio em questão. Para uma descrição do caso, v. KOMMERS, 2012, posição 10345 e ss. 
de direitos fora do catálogo. Existe, porém, um aspecto importante que as diferencia. Enquanto a noção de direito geral de liberdade opera predominantemente no quadro da dimensão negativa dos direitos, limitando a intervenção do estado na autodeterminação individual, as cláusulas de não exaustividade têm alcance mais amplo, enunciando a incompletude da enumeração textual de todas as categorias de direitos, de modo a abarcar também os que expressam valores como solidariedade e igualdade, e abarcando, portanto, os direitos em sua dimensão prestacional (MARTINEZ-PUJALTE, 1997, p. 57; MARTINEZ, 1995, p. 365).

No que tange ao valor liberdade, recentemente, a Corte Constitucional alemã reconheceu o direito à autodeterminação na morte, conferindo proteção à liberdade individual de definir o fim da própria vida, o que inclui, mas não se exaure, na possibilidade do suicídio assistido. A garantia, não enumerada, foi extraída do direito geral de personalidade, do qual, segundo esse tribunal decorre a liberdade geral de ação ${ }^{26}$.

A prática jurisprudencial revela que as Cortes não se limitam ao valor liberdade na construção de novos direitos. Como exemplo de direito fundamental não enumerado embasado no valor igualdade, também o Tribunal Constitucional Federal alemão afirmou, em 1993, o direito a ações afirmativas com recorte de gênero, com o objetivo de fomentar a igualdade de condições entre homens e mulheres no mercado de trabalho ${ }^{27}$. Já como exemplo de direito não escrito baseado na solidariedade, destaca-se o reconhecimento, pelo Supremo Tribunal Federal (STF), do direito ao mínimo existencial, justificado à luz do objetivo fundamental da república de redução da pobreza, marginalização e redução das desigualdades sociais e regionais, bem como no princípio da dignidade da pessoa humana ${ }^{28}$.

\footnotetext{
${ }^{26}$ ALEMANHA. Tribunal Constitucional Federal Alemão. 2 BVerfGE 2347/15 (2020).

27 ALEMANHA. Tribunal Constitucional Federal da Alemanha. 89 BVerfGE 276 (1993). Segundo Kommers (2012, posição 11166), o esforço da Corte de desenvolver uma linha jurisprudencial sobre ações afirmativas acabou sendo superado pelo constituinte derivado, que, no ano seguinte a essa decisão, reformou o art. $3^{\circ}$, (2), da Constituição alemã, estabelecendo, com isso, uma base textual a esse direito.

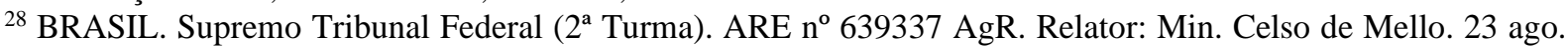
2011. DJe 15 set. 2011. A Corte aduziu que esse direito é precondição ao exercício do direito geral de liberdade, além de embasar o direito a certas prestações positivas: "A noção de mínimo existencial, que resulta, por implicitude, de determinados preceitos constitucionais $\left(\mathrm{CF}\right.$, art. $1^{\circ}$, III, e art. $3^{\circ}$, III), compreende um complexo de prerrogativas cuja concretização revela-se capaz de garantir condições adequadas de existência digna, em ordem a assegurar, à pessoa, acesso efetivo ao direito geral de liberdade e, também, a prestações positivas originárias do Estado, viabilizadoras da plena fruição de direitos sociais básicos, tais como o direito à educação, o direito à proteção integral da criança e do adolescente, o direito à saúde, o direito à assistência social, o direito à moradia, o direito à alimentação e o direito à segurança".
} 
Retomando o estudo das previsões que estabelecem o caráter aberto dos catálogos de direitos fundamentais, entendemos que a eficácia interpretativa dessas normas é inegável em um modelo de normatividade constitucional. Menos decisivo parece ser o debate sobre se os direitos implícitos decorreriam diretamente dessas disposições, ou de outras normas abertas que prevejam direitos fundamentais, até porque a prática jurisdicional demonstra que, em geral, não é usual que o reconhecimento de um direito implícito se faça pelo recurso a um enunciado constitucional de forma isolada, como se tratasse de uma operação interpretativa simples.

Entendemos que, na prática judicial, o reconhecimento de direitos implícitos é alcançado pelo emprego de construções constitucionais, compreendidas, em síntese, como operações de teor criativo mais acentuado que a mera interpretação, essa última compreendida como a extração do sentido explícito, ou daqueles que, embora implícitos, pareçam decorrer de um enunciado normativo de forma mais intuitiva. A legitimidade e limites das construções no direito constitucional em geral é tema que exige estudo autônomo (v. GONÇALVES, 2016). No caso específico dos direitos fundamentais, todavia, consideramos que o art. $5^{\circ}, \S 2^{\circ}$, do texto constitucional, consagra, de forma expressa, o recurso a operações hermenêuticas robustas como método de tutela de direitos fundamentais não escritos. Ademais, a ampla admissão da normatividade dos princípios - estrutura normativa de boa parte dos direitos fundamentais -, associada à abertura semântica desses enunciados, instauram terreno fértil ao reconhecimento de novos direitos (PEREIRA, 2018).

No cenário brasileiro, exemplo de construção constitucional de direitos foi o reconhecimento, pelo Supremo Tribunal Federal, do direito fundamental à não autoincriminação, garantia implícita extraída do devido processo legal e do direito ao silêncio ${ }^{29}$.

Como técnica que se insere no fenômeno mais amplo de desenvolvimento judicial do direito, as construções não costumam ser estáticas, mas decorrentes de um processo de sedimentação ${ }^{30}$, que se firma através de múltiplas decisões. Neste sentido, após o reconhecimento inicial do direito à não autoincriminação, essa garantia passou por novos

\footnotetext{
${ }^{29}$ BRASIL. Supremo Tribunal Federal (1 $1^{\text {a }}$ Turma). HC no 68929/SP, Relator: Min. Celso de Mello. 22 out. 1991. DJ 28 ago. 1992.

${ }^{30}$ Barry Friedman e Scott Smith (1998, p. 36 e ss.) empregam a metáfora da sedimentação constitucional para descrever como o texto da Constituição - que, inicialmente, seria como um terreno plano - passa por sedimentações ao longo do tempo, à medida em que se agregam novos significados às suas previsões através da interpretação, algumas cláusulas adquirindo o formato de verdadeiras montanhas de desenvolvimento histórico.
} 
desdobramentos. Assim, embora inicialmente reconhecido como aplicável ao processo penal, o STF ampliou o escopo desse direito em decisões posteriores, entendendo que essa garantia é aplicável, também, nas Comissões Parlamentares de Inquérito, uma vez que "a garantia contra a autoincriminação se estende a qualquer indagação por autoridade pública de cuja resposta possa advir à imputação ao declarante da prática de crime, ainda que em procedimento e foro diversos" ${ }^{31}$, bem como que seu exercício se estende a qualquer testemunha, indiciado, ou réu ${ }^{32}$.

É possível, ainda, que a concepção de direitos não enumerados trilhe um caminho inverso. Nesses casos, inicialmente, confere-se proteção jurídica a aspectos setoriais, que decorrem desse direito, para, apenas em etapa subsequente, admiti-lo como direito autônomo. Este foi o caso da proteção jurídica das uniões homoafetivas no Brasil. Antes de o STF reconhecer essa entidade familiar como uma modalidade de união estável, com todos os efeitos jurídicos daí decorrentes, essa união já era contemplada em questões tributárias e previdenciárias $^{33}$.

Tem-se, então, a possibilidade de construção de direitos fundamentais implícitos de ordem centrífuga, ou centrípeta. No primeiro caso, o direito é construído em etapa inicial, com a consequente irradiação de efeitos secundários em decisões posteriores. No segundo, parte-se da proteção de aspectos setoriais decorrentes desse direito, para, com isso, formar-se um movimento que resulta no seu reconhecimento como garantia autônoma. A classificação pode ser correlacionada com os conceitos de ativismo de ponto de partida e de chegada ${ }^{34}$.

\footnotetext{
${ }^{31}$ BRASIL. Supremo Tribunal Federal (Tribunal Pleno). HC no 79244/DF, Relator: Min. Sepúlveda Pertence. 23 fev. 2000. DJ 24 mar. 2000.

32 BRASIL. Supremo Tribunal Federal (Tribunal Pleno). HC no 79812. Relator: Min. Celso de Mello. 08 nov. 2000. DJe 16 fev. 2001.

${ }^{33}$ Neste sentido, em âmbito federal, a Procuradoria-Geral da Fazenda Nacional elaborou o Parecer PGFN/CAT/N ${ }^{\circ}$ 1503/2010, de 2010, opinando pela juridicidade da inclusão de companheira homoafetiva para fins de dedução de Imposto de Renda. Na esfera local, o estado do Rio de Janeiro, em 2007, editou a Lei $\mathrm{n}^{\circ}$ 5.034, equiparando os casais homoafetivos às uniões estáveis heterossexuais para fins previdenciários. Quanto às decisões judiciais proferidas em tribunais estaduais, análise estatística apontando fortes oscilações e uma tendência ao firmamento do entendimento favorável à equiparação entre as uniões estáveis como majoritário, a partir de meados de 2009, pode ser consultada no estudo de Claudia Rosane Roesler e Paulo Alves Santos (2014, p. 622).

${ }^{34} \mathrm{O}$ conceito de ativismo de ponto de partida e de chegada diz respeito ao percurso das discussões sobre direitos fundamentais judicializados, conforme estas se iniciem, ou desemboquem no STF, após serem debatidas em outras esferas como o legislativo, ou instâncias inferiores (PEREIRA, 2016, p. 135-139).
} 
Por fim, mais recentemente, tem ganhado destaque no STF o tema do direito ao esquecimento, empregando a Corte, em decisão da Segunda Turma, a mesma linha de fundamentação acerca de sua existência em sede constitucional:

"[O] direito ao esquecimento, a despeito de inúmeras vozes contrárias, também encontra respaldo na seara penal, enquadrando-se como um direito fundamental implícito, corolário da vedação à adoção de pena de caráter perpétuo e dos princípios da dignidade da pessoa humana, da igualdade, da proporcionalidade e da razoabilidade" 35 (extraído do voto do Relator).

A existência de um direito ao esquecimento não foi ainda apreciada pelo Tribunal Pleno do STF, estando pendente de julgamento perante essa Corte, ainda, os contornos desse direito na esfera privada ${ }^{36}$. Embora nos pareça intuitiva a existência de um direito ao esquecimento em caráter prima facie, como consectário implícito dos direitos à privacidade e intimidade, a existência de um direito definitivo com essa configuração na ordem constitucional brasileira que protege, também, as liberdades de expressão e informação - é questão mais complexa. Falase, ainda, no direito à memória como antagônico ao reconhecimento desse direito. Também entra em cena, nesse contexto, o papel dos valores na construção de direitos fundamentais não enumerados, que exige análise em separado e é tratado no tópico a seguir.

\subsection{Recurso a valores ou a considerações de justiça}

A noção de que a aplicação dos direitos fundamentais envolve uma dimensão ética ganhou força no contexto do pós-positivismo. Na jurisprudência contemporânea, tornou-se largamente disseminada a ideia de que a interpretação de direitos baseados em conceitos abertos encerra a análise de valores. No tópico antecedente, mencionamos a possibilidade de reconhecimento de direitos fundamentais não enumerados a partir da interpretação de normas constitucionais que enunciam categorias com facetas morais, tais como liberdade, igualdade e solidariedade. O presente tópico trata de questão distinta, qual seja, a das concepções morais vigentes em uma sociedade e seu papel na construção de direitos. Sob esse ângulo, entendemos que a questão pode ser mais bem explicada decompondo a sua análise em dois cortes. De um

\footnotetext{
${ }^{35}$ BRASIL. Supremo Tribunal Federal (2 ${ }^{\mathrm{a}}$ Turma). HC 126315/SP. Relator: Min. Gilmar Mendes, 15 set. 2015. DJe 07 dez. 2015.

${ }^{36}$ BRASIL. Supremo Tribunal Federal (Tribunal Pleno). ARE 833248 RG. Relator: Min. Dias Toffoli, 11 dez. 2014. DJe 20 fev. 2015, Tema de Repercussão Geral n 786: “Aplicabilidade do direito ao esquecimento na esfera civil quando for invocado pela própria vítima ou pelos seus familiares".
} 
lado, temos o prisma temporal, relacionado à evolução dos valores pelo transcurso do tempo. De outro, temos a perspectiva transnacional, relacionada ao fato de que as influências culturais entre os países geram mudanças de valores que repercutem na leitura das normas com conteúdo aberto.

Sob o ângulo temporal, os valores que se relacionam aos direitos fundamentais não enumerados guardam relação com as visões sociais dominantes sobre justiça e manifestações culturais que as reflitam em um determinado momento. A defesa do reconhecimento de direitos não enumerados através do recurso a considerações morais liga-se ao entendimento de que os textos normativos não seriam estáticos, perpetuamente atrelados à compreensão do constituinte ao positivá-lo, mas que o sentido destes evoluiria ao longo do tempo. Tal forma de interpretar decorre da compreensão do fenômeno constitucional a partir de uma dupla dimensão, isto é, a de que haveria, simultaneamente, a Constituição como norma jurídica e a constituição real, entendida como o conjunto de forças políticas e sociais relevantes do ponto de vista constitucional. Nesse contexto, fenômenos como o reconhecimento de direitos não enumerados e a mutação constitucional inserem-se no quadro de coordenação entre texto constitucional e realidade. Como se sabe, a evolução constitucional das sociedades não depende exclusivamente de reformas constitucionais por mecanismos formais de emenda, operando-se também a partir da transformação do significado das normas que envolvem conceitos abertos, que passam por atualizações mesmo quando os textos que as embasam permanecem inalterados (PEREIRA, 2018, p. 67-8).

Na metáfora frequentemente empregada pela Suprema Corte canadense, a Constituição - e, em especial, a Carta de Direitos Fundamentais de 1982 - é como uma árvore viva (living tree), que passa por crescimentos e expansões, embora de forma circunscrita a certos limites naturais relacionados aos vocábulos objeto de interpretação ${ }^{37}$. Essa concepção parte da premissa de que a virtude dos textos constitucionais é, exatamente, a sua adaptabilidade a novos

\footnotetext{
${ }^{37}$ No caso Reference re Same-Sex Marriage, a Suprema Corte canadense descreveu a doutrina da constituição como uma árvore viva como um dos princípios fundamentais da interpretação constitucional desse país, permitindo a adaptação do texto a novas realidades, através de uma leitura progressista. CANADA. Suprema Corte do Canadá, 3 SCR 698 (2004). Como ensina Asher Honickman (2019, p. 29), essa doutrina teve origem no caso Edwards $v$. Canada (Attorney General), de 1929, encerrando a ideia de que a constituição deve ser adaptável a novas realidades econômicas e sociais.
} 
contextos históricos, possível em razão de sua enunciação em terminologia aberta e não raro evocativa de leituras permeadas por análises valorativas.

Identificar o recurso a valores como critério de justificação dos direitos fundamentais não enumerados, distinto do mero reconhecimento a direitos implícitos, é mais simples quando analisamos países cujo texto constitucional não foi alterado ao longo do tempo. Neste sentido, é intuitivo que a evolução da jurisprudência constitucional na seara das questões moralmente controvertidas, mantido o texto constitucional, é impactada pela evolução dos valores socialmente dominantes. Considerando o longo histórico de superações pela Suprema Corte norte-americana de seus próprios entendimentos anteriores, em decisões tomadas sob o mesmo texto constitucional, não é plausível imaginar que todos os entendimentos jurisprudenciais atuais expressem visões que, em verdade, se encontravam implícitas no texto constitucional desde tempos imemoriais, de forma estática ${ }^{38}$.

Nessa linha, para Thomas Grey, a previsão em Constituições de normas como as que esclarecem o caráter aberto do sistema de direitos fundamentais e a positivação das normas de direitos fundamentais específicos com o uso de linguagem vaga e abstrata cumpre a função de permitir que os juízes, acessando os valores básicos da comunidade, que sofrem variações ao longo das diferentes gerações, atualizem o conteúdo das disposições de direitos ao longo do tempo (GREY, 1975, p. 709). No entanto, uma das críticas que se apresenta a esse entendimento é a que diz respeito à real capacidade dos juízes de captar essas ditas mudanças sociais e, a partir disso, atualizar a interpretação da Constituição. Nesse sentido, John Hart Ely (2010, p. 88) argumenta que a noção de veiculação pelo judiciário dos "valores amplamente partilhados" pressupõe que estes existam e que possam ser objeto de descoberta e conhecimento - inclusive por juízes. Para esse autor, nenhuma dessas pressuposições é verdadeira. Em suas palavras, é ridículo supor que o judiciário disponha de maiores condições do que o legislativo para identificar a moral convencional de um dado momento (Ibidem, p. 90).

Nessa ordem de ideias, uma dificuldade associada a essa tese é identificar qual acervo de valores poderia ser legitimamente invocado no reconhecimento de direitos não enumerados. É possível exemplificar o ponto recorrendo ao Acórdão nº 130/88, do Tribunal Constitucional de Portugal, que reconheceu o direito à disposição sobre o próprio corpo após a morte,

\footnotetext{
${ }^{38}$ Sobre a prática de superação de seus próprios precedentes constitucionais pelos órgãos de cúpula do judiciário dos Estados Unidos, Reino Unido e Brasil, v. GONÇALVES, 2018, p. 415 e ss.
} 
entendendo como constitucional a recusa à doação de órgãos quando fundada em razões éticas, filosóficas ou religiosas. Chama atenção que, na fundamentação do reconhecimento desse direito fora do catálogo, o Tribunal tenha recorrido a escritos da doutrina cristã para reconhecer que a doação não configura ato de caridade obrigatório:

\footnotetext{
"Neste mesmo sentido se pronunciou Pio XII, ao afirmar, acerca da colheita de córneas, que 'a não ser que as circunstâncias imponham uma obrigação, é preciso respeitar a liberdade dos interessados' e que, 'habitualmente, o caso não se apresentara como um dever ou um acto de caridade obrigatório'.

(...)

O Papa João Paulo I, sem embargo de acentuar a necessidade de se agir com respeito da pessoa e do seu próximo, fala em trabalho imenso posto ao serviço da vida humana para a prolongar em condições humanas (mensagem aos participantes do $7^{\circ}$ Congresso Internacional da Sociedade de Transplantação em Roma, 6.9.78)".
}

Nas democracias ancoradas no pluralismo político, social e religioso, é natural o ceticismo quanto à capacidade e legitimidade do judiciário para atualizar ou preencher o sentido das disposições constitucionais em nome do povo, bem como quanto aos tipos de valores que podem ser legitimamente aplicados nesse processo. Nesse contexto, o uso de razões religiosas em decisões judiciais criativas pode ser um sinal de alerta quanto aos riscos e limites da judicialização. Embora não seja viável esgotar essas questões no presente estudo, deve ser considerado, de início, que nem sempre a atuação do judiciário na atualização dos direitos fundamentais se dá de forma isolada. É muito conhecido o exemplo da chamada Era dos Direitos Civis norte-americana, em que o papel da Suprema Corte foi o de ratificação de mudanças sociais explicitamente iniciadas no contexto social, não só por mudanças em práticas culturais, como pela via de adoção de novas leis sobre o assunto e pela manifestação oficial de apoio à causa por parte do poder executivo ${ }^{39}$.

\footnotetext{
${ }^{39}$ Nesse período, promoveu-se uma substancial alteração da compreensão da sociedade norte-americana acerca da igualdade em questões raciais. A mudança no ethos social dominante não foi (nem poderia ser exclusivamente) fruto de uma alteração da Constituição formal, mas sim de um processo de mudança jurisprudencial e legal que durou mais de uma década, tendo como um de seus pontos cruciais a decisão da Suprema Corte em Brown vs. Board of Education, em 1954. A decisão esteve no centro de um enorme e duradouro debate sobre a questão racial naquele país, do qual, dadas as manifestações da população nas eleições, com vitórias acachapantes nos poderes legislativo e executivo de candidatos favoráveis ao avanço da agenda racial, decorreram respostas institucionais como os Civil Rights Acts, de 1964 e 1968, bem como o Voting Rights Act, de 1965, posteriormente ratificados pela Suprema Corte em decisões unânimes. Juntos, esse conjunto de manifestações populares e institucionais pelos três poderes constituem o que Bruce Ackerman descreveu como um dos maiores atos de soberania popular da história norte-americana, inaugurando uma nova era na história constitucional desse país sem que qualquer alteração do texto formal tenha ocorrido, já que as alterações no direito positivo escrito foram implementadas a partir de leis ordinárias. Nesse caso, considera-se que o judiciário não foi protagonista, mas apenas um dos atores institucionais envolvidos na atualização do sentido das garantias constitucionais. Para uma detalhada exposição do processo descrito, v. ACKERMAN, 2007, p. 1757-1792.
} 
No caso brasileiro, o reconhecimento, pelo Supremo Tribunal Federal, da possibilidade de interrupção da gestação em caso de anencefalia ${ }^{40}$ e de proteção às uniões homoafetivas ${ }^{41}$ são exemplos claros de acórdãos em que a evolução dos valores socialmente dominantes teve papel relevante. No primeiro precedente, o Min. Celso de Mello destacou o papel do movimento feminista na afirmação da visão da igualdade da mulher e da compreensão desta como sujeito de direitos autônomo. No segundo, a evolução da moralidade social na compreensão da ideia de família foi aspecto ressaltado pela maioria da Corte. Outro caso que se reconduz a essa modalidade de justificação diz respeito ao direito à identidade de gênero, que, conforme definiu o STF, engloba o direito subjetivo à alteração do nome e da classificação do gênero na certidão de nascimento, independentemente de sujeição a cirurgia de redesignação ${ }^{42}$. Nessa última decisão, a Corte invocou, expressamente, os valores do bem-estar e da justiça, como fundamentos do reconhecimento do direito.

De outro lado, o recurso a valores surge também pela intepretação com perspectiva transnacional. Algumas construções judiciais de direitos não enumerados baseiam-se em concepções prevalentes em ordens jurídicas estrangeiras. Nas últimas décadas, as cortes têm cada vez mais citado e usado como inspiração julgados de outros países. Esse fenômeno surge a partir do estabelecimento de diálogos institucionais e jurisprudenciais entre sistemas distintos, muitas vezes desencadeando embates entre perspectivas divergentes e acarretando a superação das intepretações nacionais sedimentadas. Entendimentos a respeito de questões morais controvertidas, nesse contexto de intercâmbio, passam a circular globalmente, alcançando, muitas vezes, locais distintos daqueles onde foram originariamente gestados ${ }^{43}$.

O uso de argumentos calcados em valores por meio da referência a julgados de outros países coloca em pauta a controvérsia sobre se questões constitucionais são ou não universalizáveis. Entra em cena, assim, a disputa teórica que opõe universalismo e contextualismo (também chamado particularismo ou culturalismo). Enquanto o primeiro visualiza as constituições e direitos humanos como artefatos emanados da evolução da sociedade, que visam a maximizar valores e pautas éticas que devem ser comuns aos vários

\footnotetext{
${ }^{40}$ BRASIL. Supremo Tribunal Federal (Tribunal Pleno). ADPF nº 54. Rel.: Min. Marco Aurélio. 12 abr. 2012. DJe 30 abr. 2013.

${ }^{41}$ BRASIL. Supremo Tribunal Federal (Tribunal Pleno). ADI n ${ }^{\circ} 4277$ e ADPF n ${ }^{\circ}$ 132. Rel.: Min. Ayres Britto. 05 mai. 2011. DJe 14 out. 2011.

${ }^{42}$ BRASIL. Supremo Tribunal Federal (Tribunal Pleno). ADI n ${ }^{\circ}$ 4275. Rel.: Min. Marco Aurélio. 01 mar. 2018. DJe 07 mar. 2019.

${ }^{43}$ Uma sistematização seminal do assunto é feita por SLAUGHTER, 1994.
} 
sistemas, os segundos ressaltam as singularidades de cada cultura, que devem ser resguardadas na formulação das leis e na interpretação jurídica ${ }^{44}$.

O universalismo parte da premissa de que a própria ideia de constitucionalismo encerra certos valores basilares e direitos humanos válidos em todos os contextos. Nessa moldura, a hermenêutica constitucional de matriz universalista parte da premissa de que há princípios comuns a todos os sistemas, e, consequentemente, a análise e comparação das diversas interpretações sobre os valores universais permite aperfeiçoá-los. Trata-se de enfoque orientado ao aprimoramento de ideais de justiça para além das fronteiras políticas ${ }^{45}$. Aproxima-se desse debate - e, especificamente, da perspectiva universalista - a ideia de cosmopolitismo constitucional, que busca descrever o fenômeno de intercâmbio crescente de valores e compreensões entre juízes a respeito de questões constitucionais, que tendem a ser enfrentadas pelas cortes em diversos países (KUMM, 2013).

Já o culturalismo envolve a crença de que as constituições são expressões de conjunturas locais e das singularidades culturais e institucionais de cada sistema nacional. Por essa lente, as interpretações sobre os conteúdos de direitos fundamentais devem ser vistas como construções culturais relativas e atreladas às práticas sociais de cada país. O uso do direito comparado, portanto, não deve pressupor neutralidade ou assimilação pelo intérprete, mas priorizar a compreensão do contexto em que se inserem as culturas jurídicas (HIRSCHL, 2014, p. 198).

A argumentação calcada em valores transnacionais, especialmente no que se refere aos direitos humanos, expressa muitas vezes uma mensagem vocalizada pelas cortes de alinhamento ético com outras nações. Como bem observa Hirschl, "O que os tribunais constitucionais e os juízes consideram como fontes de referência "relevantes" ou "irrelevantes" reflete em grande parte sua visão de um conjunto concreto de valores aos quais desejam que seu país seja associado e o clube "certo" de nações às quais eles preferem que seu país pertença" (HIRSCHL, 2014, p. 22).

Um exemplo do uso de elementos transnacionais baseado em valores para justificar o reconhecimento e a proteção de direitos não enumerados pode ser observado no caso State $v$

\footnotetext{
${ }^{44}$ Trata-se de tema central nos debates sobre método em direito constitucional comparado. Veja-se sobre o assunto, HIRSCHL, 2014.

${ }^{45}$ Cf. sobre o tema JACKSON; TUSHNET, 2014, p. 60.
} 
Makwanyane and Another, decidido em 1995 pela Corte Constitucional da África do Sul. Na ocasião, a Corte entendeu que a pena de morte seria incompatível com a Constituição da República da África do Sul de 1993, que não dava uma resposta definitiva sobre o tema. A decisão destacou, dentre outras coisas, que a jurisprudência comparada de "declaração de direitos" seria de importância indubitável. Assim, a Corte mencionou e analisou diversos tratamentos jurídicos sobre o tema, incluindo o de países como Namíbia, Estados Unidos da América, Índia e Alemanha, e Tratados Internacionais e o Direito Internacional Consuetudinário, como o Pacto Internacional de Direitos Civis e Políticos e a Convenção Europeia dos Direitos Humanos, e decisões de tribunais internacionais, como o Comitê de Direitos Humanos das Nações Unidas, a Corte Interamericana de Direitos Humanos e a Corte Europeia de Direitos Humanos. Após essa análise, concluiu que "os direitos à vida e à dignidade são os mais importantes de todos os direitos humanos e a fonte de todos os outros direitos pessoais no Capítulo Três". Uma sociedade comprometida com o reconhecimento dos direitos humanos deve valorizar esses direitos acima de todos os outros, o que "deve ser demonstrado pelo Estado em tudo o que faz, inclusive na forma como pune os criminosos". Isso não é alcançado com o uso da pena de morte.

Muitas vezes as leituras universalistas e culturalistas aparecem simultaneamente numa mesma decisão, por vezes atuando em sinergia para justificar o acolhimento de um novo direito, e em outras como base de interpretações adversárias. O embate entre as visões universalista e culturalista apareceu de forma importante no julgamento de Obergefell $v$. Hodges, em que a Suprema Corte dos Estados Unidos reconheceu o direito de pessoas do mesmo sexo ao casamento. Um aspecto singular na decisão foi a referência reiterada, nos argumentos vencedores, à ideia de dignidade, categoria jurídica que ganhou expressão internacional no direito constitucional e internacional do pós-guerra, mas que não consta textualmente da Constituição norte-americana. Enquanto a opinião vencedora afirmou que "[h]á dignidade no laço entre dois homens ou duas mulheres que busquem se casar e em sua autonomia de realizar tais profundas escolhas" sustentando que dignidade não tem base constitucional naquele Sistema: "A falha nesta argumentação (reasoning), é claro, é que a Constituição não contém uma Cláusula de

\footnotetext{
${ }^{46}$ ESTADOS UNIDOS DA AMÉRICA. Suprema Corte. Obergefell v. Hodges, 576 U.S. 644 (2015), trecho do voto da maioria, redigido pelo Juiz Kennedy, em tradução livre.
} 
'dignidade', e, mesmo que o possuísse, o governo não seria capaz de conceder dignidade" ${ }^{, 47}$.

O exemplo acima mencionado indica como as fundamentações que recorrem a valores ou leituras éticas não são garantia de orientação progressista, já que podem funcionar como dispositivos argumentativos para afirmar ou negar o reconhecimento judicial de novos direitos.

\subsection{Reconhecimento de direitos concebidos pela via do costume constitucional}

O terceiro mecanismo de justificação de direitos fundamentais não enumerados é o reconhecimento de práticas sociais corriqueiras que, embora não lastreadas em disposição constitucional expressa, são socialmente aceitas como dignas de proteção jurídica. Trata-se da via do costume constitucional. O costume é tradicionalmente admitido como fonte do direito, sendo entendido como resultado de práticas sociais reiteradas que passam a ser percebidas como cogentes (BOBBIO, 1999, p. 36) ${ }^{48}$. Embora essa fonte do direito tenha maior protagonismo no common law, é possível que a positivação de direitos não escritos também seja amparada em costumes nos países de sistema jurídico romano-germânico.

Em países que adotam constituições não codificadas, o costume desempenha um papel relevante (SARMENTO; NETO, 2013, p. 538). Já nos sistemas com constituições rígidas e escritas, a discussão sobre costumes constitucionais não tem tanta atenção, mas sua existência é geralmente admitida. Na doutrina brasileira, por exemplo, Luís Roberto Barroso defende o costume constitucional como fonte do direito (BARROSO, 2009, p. 134). Já contexto português, Jorge Miranda (2000, p. 172) sustenta a possibilidade de reconhecimento de direitos fundamentais não enumerados por meio do costume.

No direito norte-americano, Akhil Reed Amar defende que a construção de direitos não enumerados por via de costumes decorre do fato de que, do núcleo da Nona Emenda, consta o direito à descoberta de novos direitos, que devem ser apurados pela observação de práticas sociais reiteradas e compreendidas como juridicamente tuteláveis (2012, p. 108). Tal leitura da

\footnotetext{
${ }^{47}$ ESTADOS UNIDOS DA AMÉRICA. Suprema Corte. Obergefell v. Hodges, 576 U.S. 644 (2015), trecho do voto dissidente do Juiz Clarence Thomas, em tradução livre.

${ }^{48}$ Para Bobbio, o costume é uma fonte que opera pelo meio do reconhecimento estatal de normas já produzidas.
} 
Nona Emenda é mais bem aceita por autores de orientação positivista, que refutam a já abordada tese de que seu texto faria menção a direitos naturais, entendendo que a cláusula de não exaustividade refere-se aos direitos construídos pela via do costume, fonte do direito tradicionalmente aceita por autores dessa orientação (MACAFFEE, 1993, pp. 148 e ss.).

Vale notar que um desafio relacionado ao estudo dos costumes como fonte de direitos não enumerados decorre da dificuldade de traçar a fronteira que separa a evolução das práticas sociais e dos valores predominantes. Com efeito, os costumes e valores que impulsionam transformações na sociedade operam em sinergia, influenciando-se reciprocamente. Há uma dimensão ética envolvida na compreensão de que uma prática deva ser considerada cogente. De outro lado, a afirmação de uma prática na realidade social repercute na valoração sobre a sua juridicidade.

Essa questão se associa a outro aspecto teórico relevante, qual seja, o de que a existência de um costume, por si só, não implica que este seja expressão de um direito fundamental não enumerado. Neste sentido, o costume que justifica o reconhecimento de um direito fundamental é aquele que valida juridicamente um comportamento que se harmoniza com o sistema constitucional. A depender da hipótese, a prática que venha a ser reconhecida como costume pode contar com respaldo social, ou institucional consolidado ao longo do tempo, ou este pode ser relativamente novo, oriundo de uma ruptura com um modelo anterior.

Ilustrativa da primeira hipótese são as práticas que, em seu conjunto, regulam os direitos do acusado no processo penal nos Estados Unidos. Como informa Akhil Amar, diversos direitos que, ao longo da história constitucional norte-americana, foram reconhecidos pela Suprema Corte, já eram, na verdade, praticados de forma generalizada por jurisdições locais. Exemplos neste sentido são as garantias que podem ser abrigadas na noção geral de ampla defesa, englobando os direitos do acusado de testemunhar e apresentar provas em geral em causa própria, ou, se assim escolher, permanecer em silêncio, sem que isso importe em prejuízo a si; a defesa por advogado apontado pelo Estado em casos de hipossuficiência; e a paridade de armas em relação à acusação (denominado direito de simetria). Todos esses direitos, antes de 
obterem reconhecimentos expressos de sua constitucionalidade pela Suprema Corte, já eram costumeiramente aplicados ${ }^{49}$.

Já no segundo campo, pode-se citar direitos não enumerados que se afirmam pela via costumeira associados ao direito à privacidade, também não enumerado pela constituição norteamericana. Nessa linha, especialmente após a conhecida decisão em Griswold vs. Connecticut, leis proibindo a distribuição de contraceptivos para pessoas não casadas passaram a ser sistematicamente desrespeitadas, caindo em desuso. Para Amar, isso induz à conclusão de que o direito ao uso de anticoncepcionais por pessoas solteiras, ao ser declarado constitucional pela Suprema Corte no caso Eisenstadt vs. Baird, em 1972, na verdade, já era percebido como um costume constitucional (AMAR, 2012, p. 121).

Ainda no campo de costumes, cuja juridicidade representa uma ruptura com uma concepção social antes dominante, pode-se citar o reconhecimento das uniões homoafetivas pelo Supremo Tribunal Federal. No precedente, foi abordado o fato de que esse tipo de entidade familiar já era fato socialmente disseminado, bem como que já havia, em alguns domínios administrativos, proteção jurídica estabelecida. Nesse sentido, em um dos votos se destacou que: “[o]s números do censo que aqui foram enunciados, por si sós, já demonstram que a união homoafetiva é um fato da vida. A união homoafetiva é uma realidade social. Tanto é realidade que já há normação secundária que permite que os parceiros homoafetivos figurem como dependentes da Previdência Social. A Receita Federal admite que eles possam ser declarados dependentes" ${ }^{~}{ }^{\circ}$. A consideração de que a formação de famílias homoafetivas é prática social reiterada, aceita juridicamente por meio de atos normativos infralegais, e que demanda proteção constitucional, encerra exemplo de reconhecimento judicial de direito não enumerado, oriundo da via do costume ${ }^{51}$, tratando-se de hipótese em que o respaldo institucional à prática era movimento recente, acompanhando uma mudança na visão social sobre o assunto.

É interessante constatar, entretanto, que, por vezes, o argumento relacionado às tradições e práticas costumeiras pode ser usado para fundamentar a oposição ao reconhecimento

\footnotetext{
${ }^{49}$ Os processos de como tais direitos originariamente foram estabelecidos por meio de práticas que acabaram por se disseminar e, após esse processo, foram considerados constitucionais é descrito detalhadamente por AMAR, 2012, p. 98-116.

${ }^{50}$ BRASIL. Supremo Tribunal Federal (Tribunal Pleno). ADI no 4277 e ADPF no 132. Rel.: Min. Ayres Britto. 05 mai. 2011. DJe 14 out. 2011 (trecho de um dos votos).

${ }^{51}$ Essa consideração não significa que as demais linhas de justificação dos direitos não enumerados não tenham sido empregadas no reconhecimento desse direito.
} 
de um direito fundamental não enumerado. Neste sentido, na já mencionada decisão da Suprema Corte norte-americana Obergefell v. Hodges, os votos dissidentes escoraram-se na afirmação de que não há uma tradição de reconhecimento do casamento como envolvendo pessoas do mesmo sexo.

Essa constatação sinaliza uma dificuldade, presente em todos os discursos de justificação de direitos não enumerados, que se manifesta de forma acentuada na seara dos costumes. É que são inevitáveis disputas sobre se as pretensões escoradas em práticas sociais reiteradas devem ser, ou não, protegidas pela constituição, já que seu reconhecimento normalmente envolve tanto a atribuição de significado a conceitos constitucionais abertos, como a colisões entre normas constitucionais.

No Brasil, a controvérsia a respeito da constitucionalidade da chamada vaquejada é ilustrativa dessa dificuldade. A vaquejada é uma atividade cultural popular praticada no nordeste brasileiro, na qual duas pessoas, montadas em cavalos distintos, tentam derrubar um touro, puxando-o pelo rabo. A prática envolve, dentre outras coisas, clausura e açoite dos animais. O STF entendeu que a festividade, embora tradicional e costumeira, é incompatível com a proibição constitucional de crueldade com animais (art. 225, inciso VII, da Constituição Federal) ${ }^{52}$. A decisão gerou forte reação social e no poder legislativo, que editou a Lei $\mathrm{n}^{\mathrm{o}}$ 13.364/2016 (com redação dada pela Lei $n^{\circ} 13.873 / 2019$ ), reconhecendo a vaquejada como manifestação cultural nacional com condição de bem de natureza imaterial integrante do patrimônio cultural brasileiro. Foi editada, também, a Emenda Constitucional no 96/2017, que inseriu na Constituição dispositivo que prevê expressamente que "não se consideram cruéis as práticas desportivas que utilizem animais, desde que sejam manifestações culturais" e que sejam "registradas como bem de natureza imaterial integrante do patrimônio cultural brasileiro, devendo ser regulamentadas por lei específica que assegure o bem-estar dos animais envolvidos". Tais medidas legislativas não foram suficientes para encerrar o debate. Tramitam no STF a ADI n 5728, cujo objeto é a declaração de inconstitucionalidade da EC nº 96/2017, e também a ADI n 5772, que abrange, além da emenda, a declaração de inconstitucionalidade das Leis $n^{\circ} 13.364 / 2016$ e $n^{\circ} 10.220 / 2014$. Toda essa discussão em torno da vaquejada explicita que qualificar uma prática social como costume constitucional ou inconstitucional, muitas

\footnotetext{
${ }^{52}$ BRASIL. Supremo Tribunal Federal (Tribunal Pleno). ADI n ${ }^{\circ}$ 4983. Relator: Min. Marco Aurélio. 06 out. 2016. DJe 27 abr. 2017.
} 
vezes, envolve conflitos entre perspectivas sociais e jurídicas distintas, gerando embates entre movimentos sociais, legislativo e o judiciário na interpretação da constituição.

\section{ENCERRAMENTO}

A análise dos discursos de justificação dos direitos fundamentais não enumerados revela que o reconhecimento destes é prática amplamente disseminada perante as altas cortes dos países que adotam constituições escritas e sistemas de jurisdição constitucional. Tomado como fenômeno individualizado da hermenêutica constitucional, dotado de peculiaridades próprias, o assunto não tem recebido atenção proporcional à sua importância.

No presente estudo, identificamos três linhas básicas de justificação dos direitos não escritos. Esse esforço de sistematização, contudo, não deve ofuscar a realidade de que o manejo dessas modalidades de argumentação na prática jurisprudencial possui complexidades e nuances.

Uma primeira dificuldade que o tema suscita diz respeito à variedade e quantidade de elementos envolvidos. Há pluralidade de normas, fundadas em substratos éticos diversos; de concepções sobre o que é devido ou digno de proteção; e de práticas sociais e culturais. Em uma determinada questão constitucional, é possível empregar os diferentes discursos de forma a produzir soluções antagônicas. Assim, em Obergefell v. Hodges, por exemplo, a análise da decisão da Suprema Corte norte-americana revela que, enquanto a maioria asseverou a existência do direito ao casamento entre pessoas do mesmo sexo através do recurso ao princípio da liberdade (textualmente reconhecido) e à ideia de dignidade (não mencionada naquela constituição), os votos minoritários destacaram a inexistência de uma tradição de proteger essa união tanto naquele país como no direito estrangeiro, buscando, com isso, demonstrar que as concepções jurídicas e sociais dominantes não amparam a existência de direito dessa natureza. No caso do direito ao esquecimento, já mencionado, a ideia de seu reconhecimento como direito fora do catálogo entra em rota de colisão com a noção de que haveria um direito à memória, também não enumerado. Nota-se, assim, que o processo de construção de direitos não textuais envolve uma operação complexa e dialética na qual vários direitos explicitamente reconhecidos 
(nos quais estariam implícitos), valores e costumes podem ser invocados seja para sustentar sua existência, seja para negá-los.

É inequívoco que o manejo dos discursos de justificação dos direitos não enumerados pelo judiciário encerra riscos democráticos. De forma associada, há, também, o perigo de banalização da prática, constatado pelo fato de que a amplitude de linhas argumentativas existentes torna possível sustentar o caráter jusfundamental de uma quantidade talvez infindável de pretensões. No limite, a própria normatividade dos direitos fundamentais é posta em xeque se esta categoria for tratada como um invólucro passível de preenchimento por qualquer conteúdo.

Esses riscos devem ser levados a sério, mas não induzem à conclusão de que o reconhecimento de direitos fundamentais não enumerados deva ser descartado. Diversos avanços humanistas foram atingidos por essa via. Soa como truísmo afirmar que a normatividade das constituições não se exaure na previsão de dispositivos textuais. Tampouco o art. $5^{\circ}, \S 2^{\circ}$, da CF/88 autoriza essa conclusão.

Nessa ordem de ideias, a contenção dos riscos associados a essa prática impõe que o judiciário atue com prudência e ônus argumentativo acentuados na construção dessa modalidade de direitos fundamentais. O desenvolvimento analítico dos parâmetros norteadores desse esforço de motivação é tarefa que será realizada em etapa subsequente da agenda de estudo inaugurada pelo presente artigo.

De toda forma, em enunciação preliminar, um desses parâmetros consiste em avaliar o grau de convergência entre os discursos de justificação identificados ao longo do presente artigo no sentido da construção do direito não enumerado. Essa tarefa envolve, de forma sucinta, analisar $a$ ) se o direito não escrito, que se busca fundamentar, pode ser razoavelmente considerado desdobramento de uma garantia constitucional expressa; $b$ ) se a evolução dos valores dominantes, tomados sob as óticas temporal e transnacional, apontam no sentido de uma maior percepção de que a pretensão em questão ostenta jusfundamentalidade; e $c$ ) se é possível constatar a existência de uma prática social reiterada que, além de ser vista como cogente, se atrele ao exercício, ou avanço de uma garantia constitucional. O grau de inovação da decisão e a vinculação à proteção de minorias são outros aspectos que essa análise deve englobar. 
Embora essa tarefa inevitavelmente envolva certa indeterminação, nos parece fora de dúvida que o reconhecimento de direitos fundamentais não enumerados, através de uma motivação consistente e adequada, é uma tarefa constitucional inevitável e necessária.

\section{REFERÊNCIAS BIBLIOGRÁFICAS}

ABRAMS, Floyd. What Are the Rights Guaranteed by the Ninth Amendment? American Bar Association Journal, v. 53, p. 1033-1039, 1967.

The ninth amendment and the protection of unenumerated rights, Harvard Journal of Law and Policy, v. 11, p. 93-96, 1988.

ACKERMAN, Bruce. The Living Constitution, Harvard Law Review, v. 120, n. 7, p. 1737$1812,2007$.

ANDRADE, José Carlos Vieira de. Os Direitos Fundamentais na Constituição Portuguesa de 1976. Coimbra: Livraria Almedina, 1998.

ALEXY, Robert. Teoria dos Direitos Fundamentais. São Paulo: Malheiros, 2008.

Teoria da argumentação jurídica. Rio de Janeiro, Forense, 2011.

AMAR, Akhil Reed. America's Unwritten Constitution: The precedents and principles we live by. New York: Basic Books, 2012.

ARNOLD, Morris S. Doing More Then Remembering the Ninth Amendment. Chicago-Kent Law Review, v. 64, p. 265-268, 1988.

BARNETT, Randy. Foreword: Unenumerated constitutional rights and the rule of law. Harvard Journal of Law \& Public Policy, v. 14, p. 615-643, 1991.

Restoring the lost constitution. New Jersey: Princeton University Press, 2005.

BARROSO, Luís Roberto. Curso de direito constitucional contemporâneo. Rio de Janeiro: Saraiva, 2009.

BOBBIO, Norberto. Teoria do ordenamento jurídico. Brasília: UNB, 1999.

CANOTILHO, José Joaquim Gomes. Direito Constitucional e Teoria da Constituição. Coimbra: Almedina, 2003.

DWORKIN, Ronald. Hard Cases. Harvard Law Review, v. 88, n. 6, p. 1057-1109, 1975. 
. Unenumerated Rights: whether and how Roe should be overruled. University of Chicago Law Review, v. 59, n. 1, p. 381-432, 1992.

Freedom's law: the moral reading of the american constitution. Oxford: Oxford University Press, 1996.

ELY, John Hart. Democracia e Desconfiança. São Paulo: Martins Fontes, 2010.

ETZIONI, Amitai. The Spirit of the Community: Rights, Responsibilities and the Communitarian Agenda. New York: Crown, 1996.

FRIEDMAN, Barry e SMITH, Scott. The sedimentary constitution, University of Pennsylvania Law Review, v. 147, n. 1, 1998, p. 1-90.

GONÇALVES, Gabriel Accioly. $O$ desenvolvimento judicial do direito: construções, interpretação criativa e técnicas manipulativas. Rio de Janeiro: Lumen Juris, 2016.

Stare Decisis horizontal e Constituição: concebendo um sistema de precedentes a serviço dos direitos fundamentais. In: BARROSO, Luís Roberto; MELLO, Patrícia Perrone Campos (Coords). A República que ainda não foi. Trinta anos da Constituição de 1988 na visão da Escola de Direito Constitucional da UERJ. Belo Horizonte: Fórum, 2018, p. 418-432.

GREY, Thomas C. Do we have an unwritten constitution. Stanford Law Review, v. 27, n. 3, p. 703-718, 1975.

FALLON JR., Richard H. The Dynamic Constitution. Cambridge: Cambridge University Press, 2004.

HIRSCHL, Ran. Comparative Matters: The Renaissance of Comparative Constitutional. Oxford: Oxford University Press, 2014.

HONICKMAN, Asher. The Original Living Tree, Constitutional Forum constitutionnel, 2019, v. 28, n. 1, p. 29-36.

JACKSON, Vickie C.; TUSHNET, Mark (Eds.). Comparative Constitutional Law. 3. ed. Oxford: Oxford University Press, 2014.

KUMM, Mattias. The Cosmopolitan Turn in Constitutionalism: An Integrated Conception of Public Law. Indiana Journal of Global Legal Studies, v. 20, n. 2, p. 605-628, 2013.

KYMLICKA, Will. Liberalism, Community, and Culture. Oxford: Oxford University Press, 1989.

KOMMERS, Donald P. The Constitutional Jurisprudence of the Federal Republic of Germany. DURHAM: Duke University Press, 2012.

LAPORTA, Francisco. Sobre el concepto de derechos humanos. Doxa, n. 4, p. 23-46, 1987. 
LARENZ, Karl. Metodologia da ciência do direito. 3. ed. Lisboa: Fundação Calouste Gulbekian, 1997.

LOCKE, John. Two Treatises of government and a letter concerning toleration. New Haven: Yale University Press, 2003.

MACAFFEE, Thomas B. Prolegomena to a meaningful debate of the "unwritten constitution" thesis. Cincinnati Law Review, v. 61, p. 107-169, 1993.

MARCOS, Edgar Carpio. El significado de la clausula de los derechos no enumerados. Cuestiones Constitucionales, v. 3, p. 3-25, 2000.

MARTINEZ, Gregorio Peces-Barba. Curso de derechos fundamentales. Madrid: Universidad Carlos III, 1995.

La Universalidad de los derechos humanos. Doxa, v. 2, n. 15 e 16, p. 613-633, 1994.

MARTINEZ-PUJALTE, Antonio-Luis. La garantía del contenido esencial de los derechos fundamentales. Madrid: Centro de Estudios Constitucionales, 1997.

MIRANDA, Jorge. Manual de Direito Constitucional. Volume IV. 3. ed. Coimbra: Coimbra Ed., 2000.

NINO, Carlos Santiago. Introdução à análise do direito. São Paulo: Martins Fontes, 2010.

PELAYO, Manuel Garcia. Derecho Constitucional Comparado. Madri: Alianza, 1993.

PEREIRA, Jane Reis Gonçalves. O judiciário como impulsionador dos direitos fundamentais: entre fraquezas e possibilidades, Revista da Faculdade de Direito da UERJ, n. 29, 2016, p. 127 157.

Interpretação constitucional e direitos fundamentais: uma contribuição ao estudo das restrições aos direitos fundamentais na perspectiva da teoria dos princípios. 2. ed. Rio de Janeiro: Saraiva, 2018.

POSNER, Richard. Legal Reasoning From the Top Down and From the Bottom Up: The Question of Unenumerated Constitutional Rights. University of Chicago Law Review, v. 59, n. 1, p. 433-450, 1992.

QUEIROZ, Cristina. Direitos Fundamentais (teoria geral). Coimbra: Coimbra, 2002.

RAPACZYNSKI, Andrezej. The Ninth Amendment and the Unwritten Constitution: The Problems of Constitutional Interpretation. Chicago-Kent Law Review, v. 64, p. 177-210, 1988.

ROESLER, Cláudia Rosane e SANTOS, Paulo Alves. Argumentação jurídica utilizada pelos tribunais brasileiros ao tartar das uniões homoafetivas, Revista Direito GV, v. 10, nº 2, 2014, p. 615-638. 
SAGER, Lawrence G. You Can Raise the First, Hide Behind the Fourth, and Plead the Fifth But What on Earth Can You Do With the Ninth Amendment. Chicago-Kent Law Review, v. 64, p. 239-264, 1988.

SANCHÍS, Luis Prieto. Justicia Constitucional y Derechos Fundamentales. Madri: Trotta, 2003.

La limitación de los derechos fundamentales y la norma de clausura del sistema de libertades. In: . Estudios sobre derechos fundamentales. Madrid: Debate, 1990, p. 153166.

SARMENTO, Daniel; NETO, Cláudio Pereira de Souza. Direito Constitucional: Teoria, história e métodos de trabalho. Belo Horizonte: Fórum, 2013.

SARLET, Ingo. A eficácia dos direitos fundamentais. Porto Alegre: Livraria do advogado, 2001.

SLAUGHTER, Anne-Marie. A Typology of Transjudicial Communication, 29 University of Richmon Law Review, v. 29, p. 99-137, 1994.

TRIBE, Laurence H.; DORF, Michael C. On Reading the Constitution. Cambridge: Harvard University Press, 1991.

TUSHNET, Mark. The United States: Eclecticism in the service of pragmatism. In: GOLDSWORTHY, Jeffrey (Coord.). Interpreting Constitutions. Oxford: Oxford University Press, 2007, p. 7-54.

Data de Submissão: 24/11/2020

Data de Aceite: 07/12/2020 